ス. ショiのト等ニヨリ行ハレタルモ，其後晚

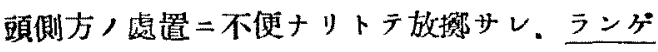
ンベゥク．七ーレンセン等／皮膚切閫=代へラ

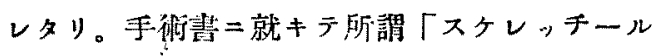
ング」ナルモノ、記载习讀ム二。喉頭

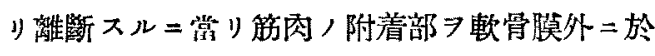
テ切斷遊離七シムル事ヨ「スケレッチールング」 ト呼ベルモノ、如シ。斯カル「スケレッチール ング」ラ便用スル以上ハ正中切開 喉頚側部，分離. 特二咽頭括䄪觔，處理，困難 ナリ。クロー，石式八軟骨膜下 =於テ喉頭 7 周 園ヨリ遊離セシ㕕ルニヨリ總テノ部位ノ「オリ エンチールング」八極メテ容易ニシテ正中切開

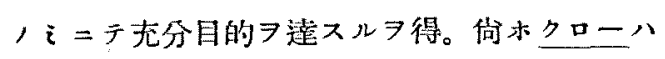

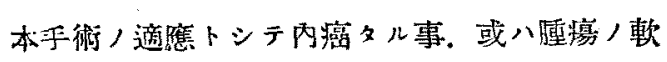
骨内二限局七几事及ビ轉移，無キ事 ヨ舉ゲ居ル

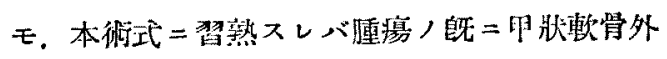
シ一部出現七ルモ，或八既二行ハレタル「ラ ヂゥム」照射ニヨリ軟骨膜炎 强固 $=$ 癒着七儿場合等 $=$ 於テ軟骨膜外 $=$ 於テ筋 肉习離斷スル要フル場合二際シテモ正中切開， $i=$ テ容易二目的》莣シ得ラル。轉移二對シテ 八二次的 ニ之ヨ摘出スレバ本術式 $=ヨ$ リ旮分處 理シ得ラル、例八刀口一自身／見解ヨリモ㲊キ 事 7 知リタリ。本手街八簡單ナル皮膚切開ノ 二テ筋肉二觸儿、事極メテ赻ク．且\%又總テ， 健康组織 =對ス几侵警

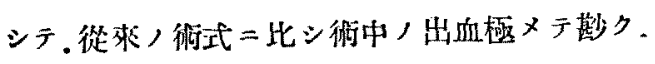
且\%患者，全身二及ボス影響並二街後，苦痛千

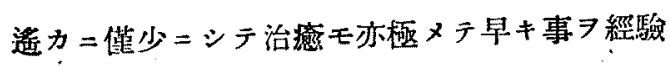

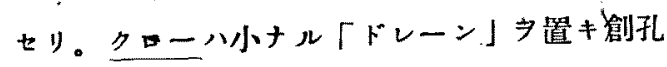
ヨ㱠ド時的二縫合スル事习推獎セルモ。斯力

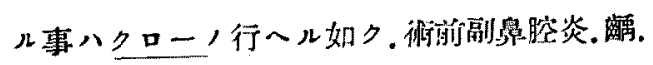

雇桃腺炎等 二治療シ初メテ可能ニシテ 本报二於テ八龠前 斯カル操作ヨ加フル事八容易ナラズ。サレバー

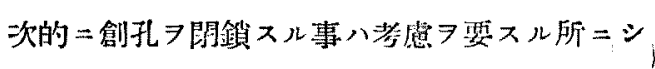

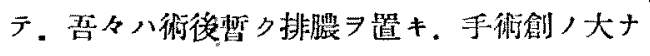
ルモノ =對シテ八適時二次的二縫合 7 行フ方針

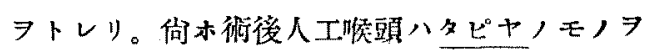
使用七り。近時各ビヤ人工喉頚トシテ市販， モノ、中ニ，拿口，型哭原型卜買ナルモ，つ リ。原型，重要ナル默习指摘シ、且ツ近來銀， 便用制限，篇「エボナイト」或ハ裴ノモノ

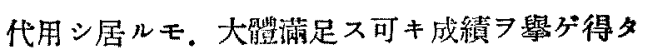
リ。最後二クロー，㗹頭摘以術式 7 活動竄真= テ倛塈セり。

\section{4. 簡單ナル氮管切開法ニ就テ}

伊䅡政 婎(長阙) 本手術八其方式二就テハ從來卜別二相遠シタ

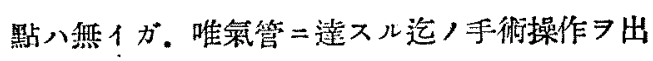
來ル本簡易化サ七タ點が特長デアル。所定，皮 膚切開後八終始其踭端幅 $2.0 \mathrm{~cm}$ ，板狀鈍鈎 $尹$ 使 用シ.乙二據ツテ組織ヨ左右网側二分割分離シ

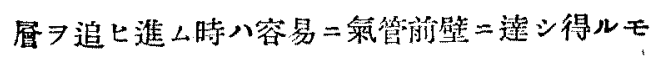
ノナル事ガ判ツ夕。同鈎二ヨル组織分襍八解剖 鑷子其他二ヨルョリモ其操作些ダ易タタルモ，

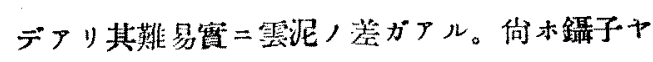

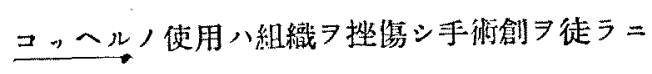
複雜セシメルノデナルガ. 反之鈎八㱠ド組織

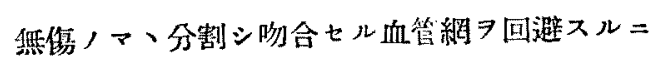
シテモ一寸鈎/跴端フ道賞添入個所ア選ブコト ニョリ容易デフリ整然卜手術习澾成シ得ル。勿

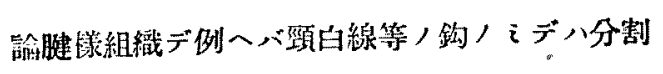

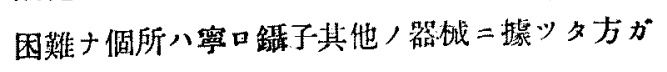
賢明デアル。斯クシテ本法八從前，法タル煩鎖 
ナ手数 二数分デ足リル。同鈎ニヨリ設ケラレタル手術 創八其受クル器械的損㑺度少ク．從ツテ手術創 八甚ダ美シク 氣管「カニユーレ」找去後, 創 ノ瘾着モ著シク早イ。

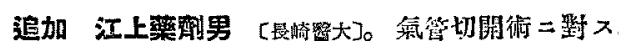
ル演者ノ考䋈二敬意キ表スル。氣管切開二際シテハ.

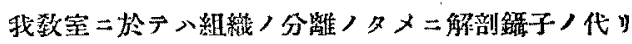
一「ハNトマン」氏耳用錹子キ用七テンル。二双， 鈍鈎八補助ノ下二.「ハルトマン」耳用鎮子キ用七

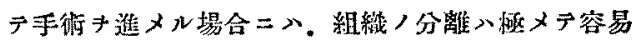

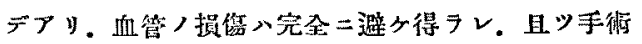
ハ極メア速二終ルコトガ出來ルノデ 些二追加スル 次第デアル。

\section{5. 人體二於方儿食道運動/電氣的 描寫二就テ}

鉿木 篤 郎(露 丠)

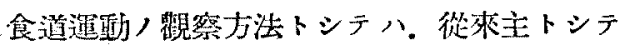
「レ」線殊ニ「レ」線活動寫䓂=依儿方法及ビ 「ゴム」球 7 食道內 =雨入シ食道內嫄曲線 寫セシメル方法 (Oesophagogramm) ガ使用七 ラレテ柬タ。一方食道運動/電籍的描寫即チ食 道運動, 際, 電氣的變勁, 消長习研究七ルモ,

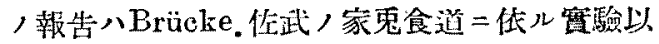

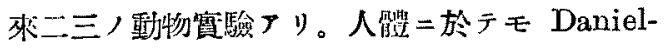
opolu + Brunetti 等/報告等アルモ一定ノ結

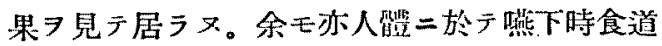
運動 $\ni$ 直接二電氣的二描寫セントシテ次ノ賽駿 ７試之夕。直徑約 $3 \mathrm{~mm}$. 長文約 $50 \mathrm{~cm}$ / 稍 キ「ゴム」管，先端二直徑約 $4 \mathrm{~mm}$. 長サ䄪 5 $\mathrm{mm}$ 人銀「メ。キ」 定シ. そタ「ゴム」管內ヨ通シタ細銅線二連 緔シ。燕下二低り食道內任意, 深サニ在ラシメ ル様ニシタ。他ノ電極八長サ約 $2 \mathrm{~cm}$. 幅 $1 \mathrm{~cm}$ 銀 板 シ以ラシ.之ヨ食監水二浸セル「ガーゼ」=
包え右手前膊部二固定シタ。兩電極間／電位差 ノ變偅八霄幅器及ビ「オッシログラフ」ラ介シ テ印畫紙上二描寫せシメル㩐ニシタ。實驗八被

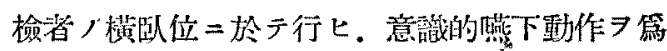
サシメタ。印狀軟骨二相當スル頸部上二小「タ

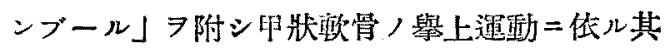
闪歷，變化二ッレ電流回路ガ閉閉スル如キ裝置

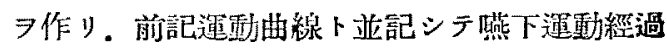
中ノ一定時 $\ni$ 自動的二標記スルコトニシタ。描 竄中十數秒間呼吸 外シタ。斯クシテ描竄シタル曲線ハニッ,成分 ヨリ成立シテ居ル。郎チ比較的速二經過スル陽

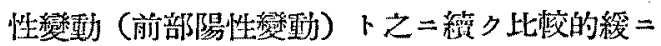
經過スル㓌性曫動（後部陰性變動）トデアル。 此二ッ, 成分八電極，食道內二於ケル位置，如 何二不關. 多ク，場合共通デアル。曲線ノ振幅 八頸部食道デハ極ク微少デアルガ. 電極，位置

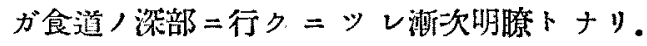

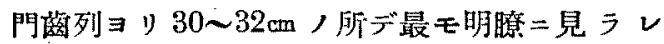
ル場合ガ多イ。之レョリ深クナルト心獩/運動 ニョル電氣的變動が曲線上=急二强ク出現シ. 国有ノ食道運動ノソレハ却テ判然タラザル場合 ガ多1。時間的關係二就テ八，前部陽性變動， 時間ハ $0.7 \sim 1.2$ 秒，後部陰性變動ノソレハ 1.5 〜2.0秒ヨ要スル。此曲線ガ食道/如何ナル爿 態ニヨリ惹起七ラル、カニ就イテハ。一䓂ニシ テ云へバ. 嚥下時食道內一定，媣サ二於ケル電 氣的變動ノ汿長，總和トシテ表現サレタルモ， ト云へル。而シテえ二關璵シ得ル要素トシテハ 次ノ如キモノガ考へラレル。1. 生物學的要素

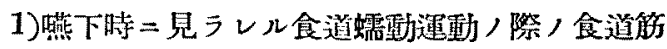

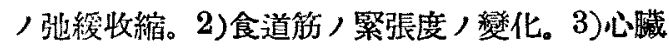
其他, 近接器官, 運動。2. 物理的要素。1)食 